\title{
Population parameters and sustainable status of lompa fish Thryssa baelama (Forsskal, 1775) manage through sasi approach at Haruku Village
}

\author{
Johannes M.S. Tetelepta ${ }^{1,2,{ }^{*}}$, Yuliana Natan ${ }^{1,2}$, Jesaja A. Pattikawa ${ }^{1,2}$, Agil S. Bernardus ${ }^{3}$ \\ ${ }^{1}$ Departmentt of Aquatic Resources Management, Faculty of Fisheries and Marine Science, Pattimura University, Jl. Mr. Chr. Soplanit Ambon 97233, \\ Indonesia \\ ${ }^{2}$ Maritime and Marine Center of Excellence, Pattimura University, J. Dr. J.M. Leimena, Ambon 97233, Indonesia \\ ${ }^{3}$ Department of Aquatic Resources Management, Faculty of Fisheries and Marine Science, Pattimura University, Jl. Mr. Chr. Soplanit Ambon 97233, \\ Indonesia
}

\begin{abstract}
The harvesting season of lompa fish, Thryssa baelama, through sasi, indigenous knowledge in resources management, in Haruku Village has become a socio-cultural event that attracts many people. The sasi of lompa fish has been conducted for hundreds of years. Information on the bioecology aspect of lompa fish is limited, while this information is crucial for lompa fish sustainability through the sasi approach. This study aimed to investigate some population parameters of lompa fish, its sustainability status, and proposed a sustainable management strategy for the lompa fishery of Haruku Village. Fish population parameter covers length-weight relationship, growth pattern, size distribution, sex ratio, and the body condition index. The sustainability status was assessed following the Rapfish approach. Fisheries management strategy was performed using a conceptual model framework based on Driver Pressure State Impact Response. The research shows that the total length varies between $9.2-14.3 \mathrm{~cm}$. A high relationship was found between total length and weight, and the growth pattern was an allometric negative. There was a difference in sex ratio between males and females, with females dominant. The body condition index varies over time, probably due to reproductive status. The overall sustainability status was at fair condition (61.60\%), with the ecological domain having the highest sustainable status (71.07\%) and considered sustain. In comparison, the technological domain had the lowest sustainability status (52.58\%) and was considered fair sustain. There were seven management strategies proposed for sustainable management for the lompa fishery.
\end{abstract}

Keywords: Management strategy, Conceptual model, Driver pressure state impact response, Sasi, Indigenous knowledge

Received: Jun 22, 2021 Revised: Aug 26, 2021 Accepted: Jan 10, 2022

*Corresponding author: Johannes M.S. Tetelepta

Farmasi Atas, Lorong Sekot, Kudamati Ambon 97116, Indonesia

Tel: +62-911-3825060, Fax: +62-911-3825061, E-mail: jms.tetelepta@fpik.unpatti.ac.id

This is an Open Access article distributed under the terms of the Creative Commons Attribution Non-Commercial License (http://creativecommons.org/licenses/by$\mathrm{nc} / 4.0 /$ ) which permits unrestricted non-commercial use, distribution, and reproduction in any medium, provided the original work is properly cited.

Copyright $\odot 2022$ The Korean Society of Fisheries and Aquatic Science 


\section{Introduction}

For the people of Haruku Village, baelama anchovy, locally called ikan lompa, has a solid cultural value (Hasan, 2017; Marjanto, 2015). The Haruku community protects this fish through sasi management, which according to the account to the Haruku Village people, started approximately in the year 1600s (Hasan, 2017; Karepisina et al., 2017) and took place to the present time (Harkes \& Novaczek, 2002; Hasan, 2017; Karepisina et al., 2017; Persada et al., 2018). Sasi is a traditional indigenous knowledge in managing natural resources (Adhuri, 2004; Batiran \& Salim, 2020; Kissya, 1995; Lellotery et al., 2007; Nikijuluw, 1995). The sasi approach is based on a broad set of rules and regulations based on customary law (adat) that govern the use of natural resources (Harkes, 1999; Harkes \& Novaczek, 2002; Soselisa, 2019).

The baelama anchovy is considered a marine species, pelagic, and presumably schooling at depths of $0-50 \mathrm{~m}$. This fish is commonly found inshore in bays, lagoons, harbors, mangrove pools, and estuaries, thus apparently tolerating lowered salinities. It contributes to general clupeoid catches but no specific fishery. This fish is used in some areas in the Pacific ocean as baitfish (Froese \& Pauly, 2021; Shomura, 1977). The lompa fish is found to migrate into the river Laerisa Kayeli of Haruku Village regularly (Marjanto, 2015).

There are four types of sasi conducted in Haruku Village: marine sasi, river sasi, forest sasi, domestic sasi, where lompa fish sasi belong to marine sasi (Hasan, 2017; Karepisina et al., 2017). In the case of sasi lompa, close sasi usually lasts for one year or sometimes more. During the close sasi, kewang, the institution responsible for the management of sasi, will control and monitor the sasi area to ensure the effectiveness of sasi. Anybody caught trespassing the sasi will be penalized according to the sasi regulation. The kewang will decide when the sasi is lifted and announced to the community. The open sasi starts in the morning with traditional ceremonies performed the night before led by the kewang chief. Before the open sasi time, the river mouth was blocked with a net to protect the lompa fish from migrating out from the river. Haruku community with other visitors enter the river during open sasi and harvest the lompa fish with conventional fishing gear. The open sasi lasts for one day, the next day, the sasi is started again until the following year.

The study on the bioecology aspect of baelama anchovy is considered limited. Some of which are studies on productivity change in the sasi area in Haruku (Talakua, 2011), the ecology and management strategy of lompa fish, and Soselisa (2019) which mainly observes the open sasi and monitor the activity during open sasi. This short information shows that study on bioecology of lompa fish is scarce. Since limited bioecology information regarding the lompa fish, this study's objective was to investigate the population parameter and sustainability status of lompa fish and propose a sustainable management strategy through the ecosystem approach to fisheries based on the finding.

\section{Materials and Methods}

\section{Study site and data collection}

The study was conducted from 12 October 2020 to 14 December 2020 at the village of Haruku (Fig. 1). For baelama anchovy (lompa) fish population parameters, the sampling was done at two weeks intervals using a nylon cast net with a mesh size of 0.5 inches and a radius range of approximately $3.5 \mathrm{~m}$. All the lompa fish caught were measured (total length -TL) to the nearest 1 $\mathrm{mm}$, and body weight (W) to the nearest $1 \mathrm{~g}$. All the lompa fish obtained were then sexed and separated into male and female. Male and female lompa fish obtained were then sub-sampled to examine ovary development through ovarian color change development and classified regarding the universal scale of five stages according to Effendie (1997) and Holden \& Raitt (1974).

\section{Length size distribution and length-weight relationship}

For length size distribution, the fish size (total length) was sorted from smallest length size to largest length size and counted for the frequency of each class interval, and then displayed graphically. The length-weight relationship for lompa fish was calculated following Benedict et al. (2009); Froese (2006) with the formula of $W=a L^{b}$ where $W$ is the wet weight (g), and $L$ is the total length of the fish $(\mathrm{cm}), a$ is the constant or intercept, and $b$ is the length exponent or slope. The $W=a L^{b}$ formula is a parabolic equation and then transformed into the linear form using a logarithmic approach: $\ln W=\ln a+b \ln L$. The $a$ and $b$ values were then estimated using least-square regression following Zar (2014). The exponent $b$ value obtained from the lengthweight relationship was then applied to determine the fish growth patterns. The fish is assumed to have negative allometric growth when the $b$ values were lower than 3 , positive allometric growth if the $b$ values were greater than 3 , and isometric form of growth when $b=3$ (Benedict et al., 2009). The $t$-student test was used to test whether the $b$ is $=3$ or $b$ is $\neq 3$ (Pauly, 1984). 


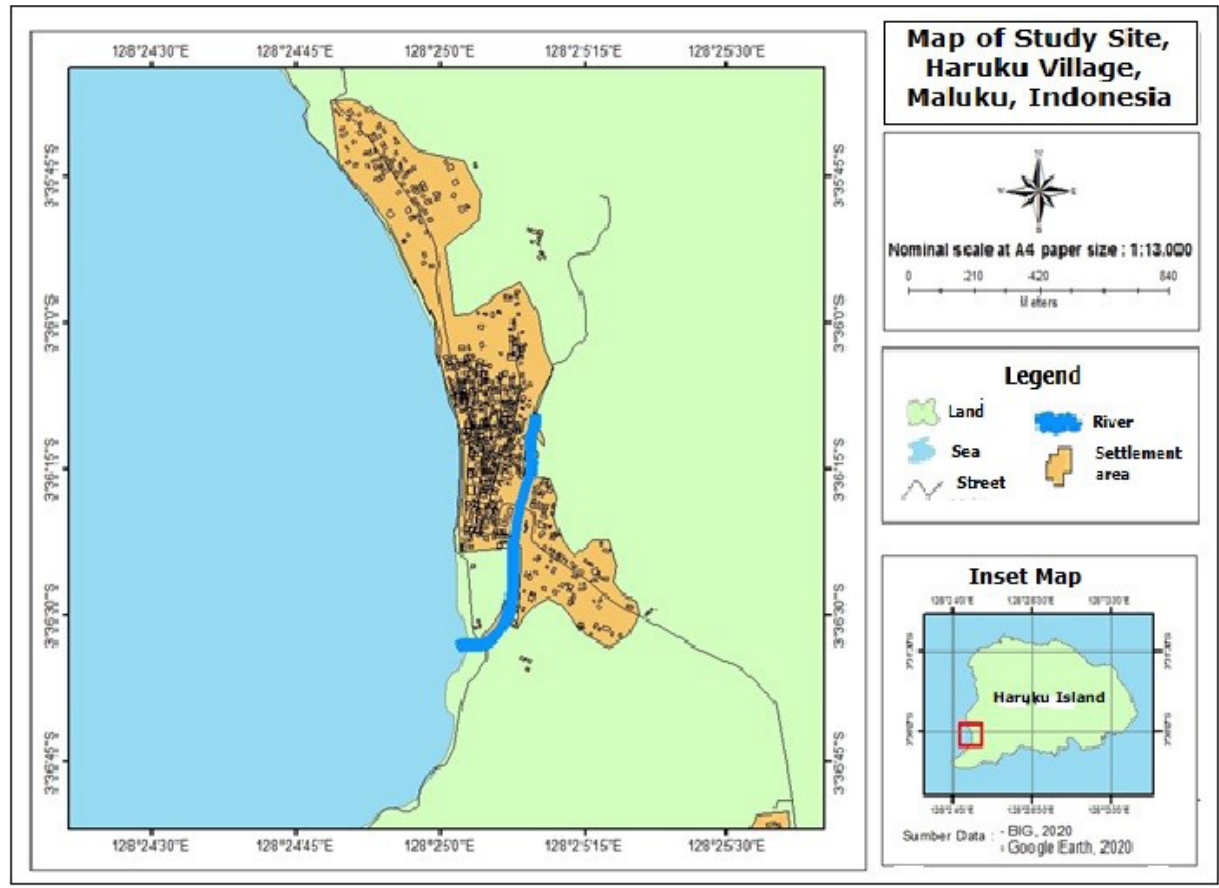

Fig. 1. Map of the study site, Haruku Village.

\section{Sex ratio, condition factor, and maturity stage}

The sex ratio was calculated by comparing males to females caught based on the sampling period and was tested for similarity using the Chi-Square test (Steel \& Torrie, 1980; Zar, 2014). The condition factor $(K n)$ of lompa fish was predicted using the formula proposed by Froese (2006) and King (2007) with the following formula: $\mathrm{CF}=\hat{\mathrm{W}} / \mathrm{W}$ where: $\hat{\mathrm{W}}$ - observed mean weight; $\mathrm{W}$ predicted mean weight $=a L^{b}$. The maturity stage analysis was conducted in relation to the open sasi period. For the lompa fish maturity stage, I was considered immature, II and III as maturing, IV as mature, and V as spent (Holden \& Raitt, 1974).

\section{Sustainability status and management strategy}

For sustainability status of lompa, the Rapid Appraisal for Fisheries (RAPFISH), a Multi-Dimensional Scaling Analysis approach was used according to Pitcher (1999); Kavanagh \& Pitcher (2004). Four domains were used for sustainability analysis covering ecological, socio-economic, technological, and institutional. The attribute for the four domains was based on Rapfish attributes (Pitcher et al., 2013) with some modifications. The attribute's name for each dimension, the number of the attribute for each dimension, and the score of each attribute are listed in Table 1.

All attributes used were then scored on the 3 to 4 Likert scale basis starting from good to bad level (Pitcher \& Prekshot, 2001; Pitcher et al., 2013). Scoring guidelines are based on the Rapfish analysis for fish sustainability status (Pitcher \& Preikshot, 2001; Pitcher et al., 2013). Data for sustainability analysis was obtained from a questionnaire distributed to 50 respondents comprising the local people, local village government, and kewang staff. All data obtained were then tabulated, and the median was used to calculate the score obtained from all respondents' answered. The sustainability analysis was done through the RAPFISH software (Kavanagh \& Pitcher, 2004), running under Microsoft Excel software version 10. The sustainability status will then be expressed on a scale from $0 \%$ (bad) to $100 \%$ (good) (Kavanagh \& Pitcher, 2004; Pitcher \& Preikshot, 2001). The sustainability classification was based on small-scale fishery's ecosystem approach to fishery management (Pitcher et al., 2009).

The Driver-Pressure-State-Impact-Response (DPSIR) conceptual model framework was used to propose a sustainable management plan. This approach has been indicated as a helpful approach in analyzing human and natural systems (Gari et al., 2015; Martin et al., 2018; Mazumder et al., 2016). Since there 
Table 1. Sustainable dimension and each of their attribute, score, and criteria used in sustainability status of lompa fish

\begin{tabular}{|c|c|c|c|c|}
\hline Dimension & Attribute & Scoring & Good & Bad \\
\hline \multirow[t]{9}{*}{ Ecology } & 1. Exploitation status & $4,3,2,1,0$ & 4 & 0 \\
\hline & 2. Species change & $3,2,1,0$ & 3 & 0 \\
\hline & 3. Fish size & $3,2,1,0$ & 3 & 0 \\
\hline & 4. Discard & $4,3,2,1,0$ & 4 & 0 \\
\hline & 5. Range of colapse & $4,3,2,1,0$ & 4 & 0 \\
\hline & 6. Migratory range & $4,3,2,1,0$ & 4 & 0 \\
\hline & 7. Habitat/ecosystem & $3,2,1,0$ & 3 & 0 \\
\hline & 8. Gonad maturity & $3,2,1,0$ & 3 & 0 \\
\hline & 9. Bycatch & $3,2,1,0$ & 3 & 0 \\
\hline \multirow[t]{11}{*}{ Socio-economy } & 1. Limited entry & $4,3,2,1,0$ & 4 & 0 \\
\hline & 2. Poverty level & $4,3,2,1,0$ & 4 & 0 \\
\hline & 3. Change in benefit & $3,2,1,0$ & 3 & 0 \\
\hline & 4. Other source of income & $3,2,1,0$ & 3 & 0 \\
\hline & 5. Market system & $3,2,1,0$ & 4 & 0 \\
\hline & 6. Equity in benefit & $3,2,1,0$ & 3 & 0 \\
\hline & 7. Social net working & $3,2,1,0$ & 3 & 0 \\
\hline & 8. Local indigenoues knowledge & $3,2,1,0$ & 3 & 0 \\
\hline & 9. Time of decision & $3,2,1,0$ & 3 & 0 \\
\hline & 10. Change in fisheries & $3,2,1,0$ & 3 & 0 \\
\hline & 11. Conflict status & $3,2,1,0$ & 3 & 0 \\
\hline \multirow[t]{8}{*}{ Technology } & 1. Change in fishing capacity & $0,1,2,3,4$ & 0 & 4 \\
\hline & 2. Change in boat size & $3,2,1,0$ & 3 & 0 \\
\hline & 3. Change in trip length & $4,3,2,1,0$ & 4 & 0 \\
\hline & 4. Gear selectivity & $3,2,1,0$ & 3 & 0 \\
\hline & 5. Gear side effect & $3,2,1,0$ & 3 & 0 \\
\hline & 6. Aggregating device & $2,1,0$ & 2 & 0 \\
\hline & 7. Fish handling & $3,2,1,0$ & 3 & 0 \\
\hline & 8. Change in fisshing effort & $3,2,1,0$ & 3 & 0 \\
\hline \multirow[t]{8}{*}{ Institutional } & 1. Governance quality quality & $4,3,2,1,0$ & 4 & 0 \\
\hline & 2. Legality & $3,2,1,0$ & 3 & 0 \\
\hline & 3. Regulation & $4,3,2,1,0$ & 4 & 0 \\
\hline & 4. Reporting & $3,2,1,0$ & 3 & 0 \\
\hline & 5. Surveilance/Monitoring & $3,2,1,0$ & 3 & 0 \\
\hline & 6. Protection & $3,2,1,0$ & 3 & 0 \\
\hline & 7. Village by law & $3,2,1,0$ & 3 & 0 \\
\hline & 8. Management plan & $3,2,1,0$ & 3 & 0 \\
\hline
\end{tabular}

Source: Pitcher \& Preikshot (2001) ; Pitcher et al. (2013).

were 36 variables used in sustainability analysis, to simplify the connectivity interaction among variables in the conceptual model framework, only one variable from each dimension with the highest sensitivity was used to construct the model (Natan et al., 2021). The conceptual model produced was then used as a management strategy for the sustainability of lompa fish.

The driver (D) component in the DPSIR conceptual model is the socio-cultural event in the harvesting season (open sasi) of lompa fish, while the pressure (P) components are the number of people participating in the harvesting season and karoro 
and mosquito net fishing gear used in the harvesting. The highest sensitivity variable towards sustainability of lompa fishery from leverage analysis of ecology, social-economy, technology, and institutional dimension was then used as state $(\mathrm{S})$ variable of DPSIR model framework. The impact (I) component is the condition of lompa fish in the sasi system. The impact can be in fish population decline, decrease in economic benefit, social conflict, etc. (Balzan et al., 2019; Kell \& Luckhurst, 2018; Mazumder et al., 2016). The response (R) component is the attempt proposed to be implemented by the kewang, the institution responsible for managing the sasi, in the form of a program or strategy to overcome the impact. The response can be at the level of D, P, S, and I. for the management instruments (Balzan et al., 2019; Díaz et al., 2018).

The relationship between all variables forming causal-effect diagrams in the DPSIR conceptual model was split up into the different elements within the DPSIR framework. Each variable was then analyzed in detail based on finding and literature review to establish a causal-effect relationship within the DPSIR (Elliott et al., 2017; Mazumder et al., 2016; Zador et al., 2017). Every management action which will be taken in association with lompa fishery was identified and broken down into different parts, introducing them in the conceptual framework and connecting as responses to the driving forces, pressures, states, or impacts (Elliott et al., 2017; Zador et al., 2017).

\section{Results}

During the research period, the total numbers of lompa fish sampled amounted to 508 individuals, with a minimum total length size of $9.2 \mathrm{~cm}$ and maximum size of $13.4 \mathrm{~cm}$, and an average size of $11.2 \mathrm{~cm}(\mathrm{SD} \pm 0.78)$. Fig. 2 shows the frequency distribution of lompa fish sampled during the study period. This figure shows that lompa fish with a total length between $11.0-11.4 \mathrm{~cm}$ was the dominant size (27.47\%).

The relationships between the length and weight of female and male lompa fish are shown in Fig. 3. This figure shows that the relationship was quite strong, with the correlation coefficient $r$ equal to 0.9475 for females and 0.9462 for males. This relationship was tested with the analysis of variance, and Table 2 shows the result. The $F_{\text {calc. }}$ is $>$ than $F_{\text {critc. (a2:0.05) }}$ signifying a highly significant correlation. The increase in length at some point will increase the weight of the fish. No information was available for T. baelama. The only available information considered close to baelama anchovy was from $T$. dussumieri from the coast of Ratnagiri, India, with a positive relationship (Pawase et al., 2020).

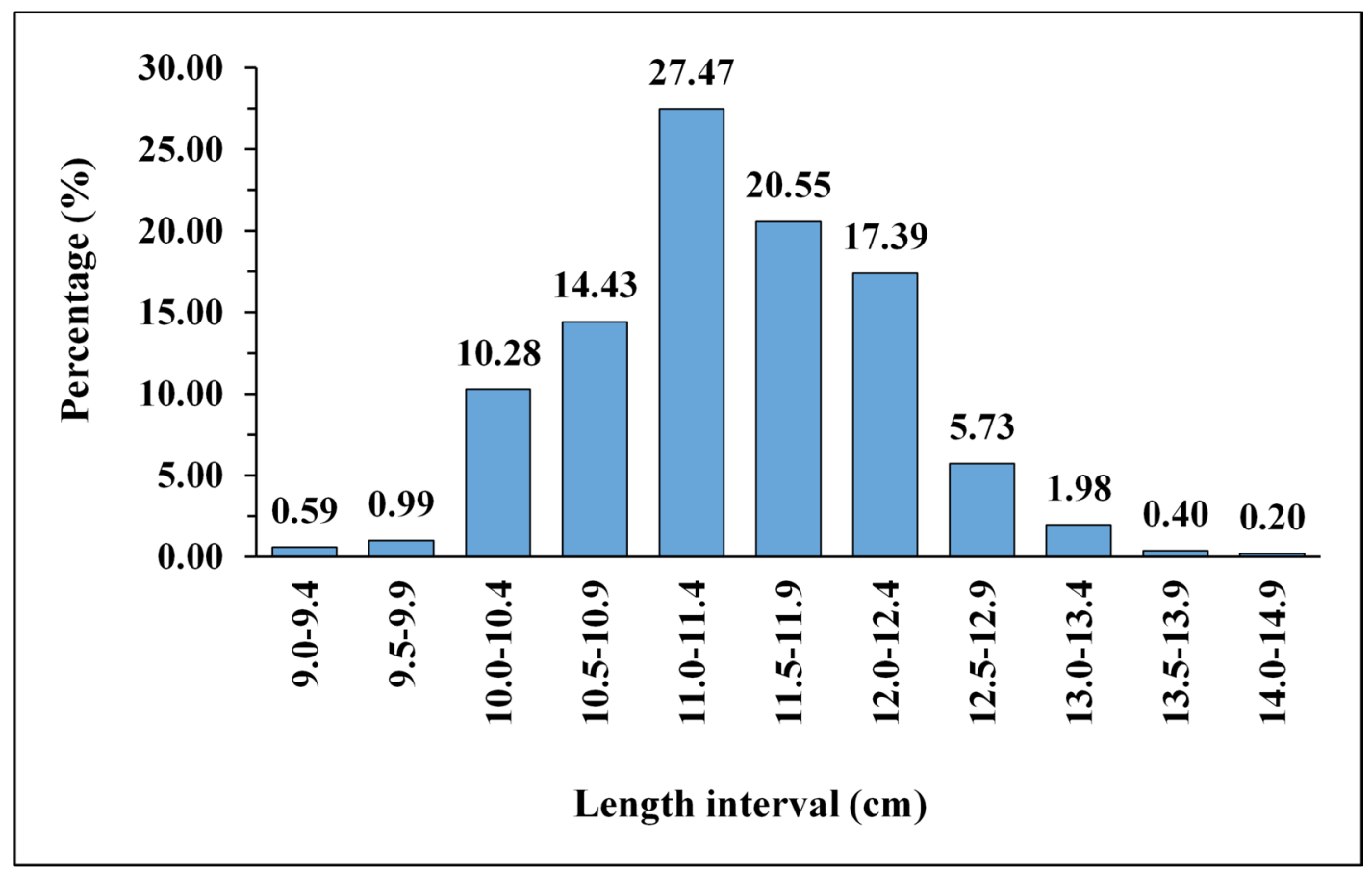

Fig. 2. Length size frequency distribution of loma fish. 


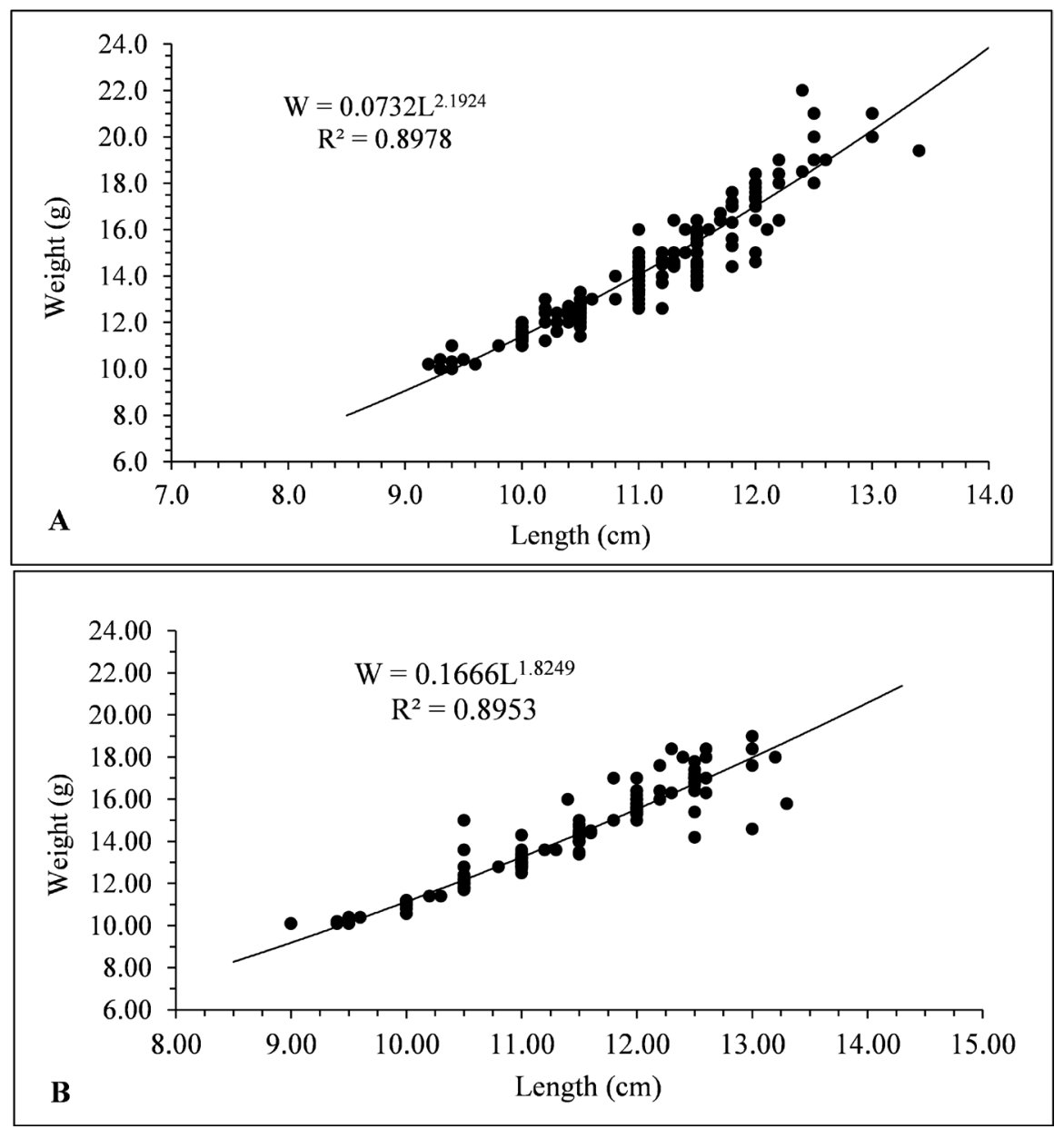

Fig. 3. Relationship between total length and weight of female (A) and male (B) baelama anchovy (lompa).

Table 2. Anova for regression between total length and weight of female and male of anchovy baelama (lompa)

\begin{tabular}{llllll}
\hline Female & $d f$ & $S S$ & $M S$ & $F_{\text {calc }}$ & Significance $F$ \\
\hline Regression & 1 & $1,223.0462$ & $1,223.0462$ & $2,288.35$ & $1.2326 \mathrm{E}-137$ \\
Residual & 283 & 151.2542 & 0.534467 & & \\
Total & 284 & $1,374.3004$ & & & \\
\hline Male & $d f$ & $S S$ & $M S$ & $F_{\text {calc. }}$ & Significance $F$ \\
\hline Regression & 1 & 774.7687 & 774.7687 & $2,177.6090$ & $2.0887 \mathrm{E}-116$ \\
Residual & 221 & 78.6293 & 0.3558 & & 5.093 \\
Total & 222 & 853.3980 & & & \\
\hline
\end{tabular}

The length-weight relationship was also performed on a monthly basis, and the result is shown in Table 3. This table shows that the length-weight relationship based on a monthly basis has a high correlation coefficient range from 0.8816 to 0.9757, and between sex was 0.9475 for females and 0.9462 for males, where the $b$ value range from 1.8249 to 2.2183 . The $t$-student test for growth pattern analysis shows that all the $t_{\text {calc. }}$ value was $>t_{\text {crit }}(\alpha 2: 0.05)$ (Table 3$)$, explaining that $b \neq 3$ indicates that the baelama anchovy had an allometric growth and, more precisely, a negative allometric growth pattern meaning the length 
Table 3. The length-weight relationship of baelama anchovy (lompa) based on monthly sampling and sexes

\begin{tabular}{llllllll}
\hline Sampling period & Ind. number & $\mathrm{W}=\mathrm{aL}^{\mathrm{b}}$ & $\mathrm{R}^{2}$ & $\mathrm{r}$ & $p$-value & $t_{\text {calc. }}$ & $t_{\text {crit. }}$ \\
\hline Total & 508 & $\mathrm{~W}=0.14471 \mathrm{~L}^{1.8969}$ & 0.8002 & 0.8957 & $3.3 \mathrm{E}-180$ & 20.754 & 1.649 \\
October & 158 & $\mathrm{~W}=0.1113 \mathrm{~L}^{1.9887}$ & 0.9520 & 0.9757 & $7.6 \mathrm{E}-102$ & 22.854 & 1.976 \\
November & 168 & $\mathrm{~W}=0.1893 \mathrm{~L}^{1.7913}$ & 0.7772 & 0.8816 & $1.23 \mathrm{E}-680$ & 12.708 \\
December & 182 & $\mathrm{~W}=0.0684 \mathrm{~L}^{2.2183}$ & 0.8392 & 0.9161 & $3.1 \mathrm{E}-720$ & 8.247 \\
Female & 285 & $\mathrm{~W}=0.0732 \mathrm{~L}^{2.1924}$ & 0.8978 & 0.9475 & $1.2 \mathrm{E}-137$ & 12.429 \\
Male & 223 & $\mathrm{~W}=0.1666 \mathrm{~L}^{1.8249}$ & 0.8953 & 0.9462 & $2.1 \mathrm{E}-116$ & 23.239 & 1.973 \\
\hline
\end{tabular}

growth is a tendency lower than weight growth.

A total number of 508 baelama anchovy individuals were sampled during the studied period between October to December 2020. The sample comprises 223 males and 285 females. Table 3 shows the sex ratio of baelama anchovy from Haruku Village. From the analysis, it was found that X2calc. $=11.7894>$ $X 2$ critc(a2):0.05 $=11.070$ meaning there is a difference between male to female. Fig. 4. displays the pooled relative condition factor $(K n)$ of baelama anchovy based on a fortnight interval from October to December 2020. This figure shows a change in relative condition factor over time, and varied between $0.99986-1.00519$.

Table 4. shows the number and percentage of occurrence of female lompa fish at a length interval of $5 \mathrm{~mm}$. This table shows that the lompa fish was found at different maturity stages at various length sizes. It was also found that the lompa fish with length intervals between 11.5-11.9 had a high number of fishes at stage IV (mature) and V (spent) (38.14\%). No lompa fish at a length size interval of 9.0 to $9.4 \mathrm{~cm}$ was found in any stage of maturity.

From the ecological sustainability status of lompa using 9 attributes, the Rapfish analysis shows that the ecological sustainability of lompa fish was $71.07 \%$ from the $100 \%$ sustainable scale (Fig. 5A). This status is considered to sustain according to the ecosystem approach to fisheries management (Pitcher et al., 2009). The Monte Carlo scatter plot (Fig. 5B) shows the Rapfish ordination's stability shown by the plot's clumpiness. The stress value from Rapfish analysis was 0.1418 , which is $<0.25$, indicating the high goodness of fit of the test (Clarke et al., 2014). From all attributes used, the most sensitive attribute to the sustainability of lompa fish was the range of collapse (Root Mean Square = 4.34).

The range of collapse attribute assesses if there is evidence of geographic range reduction of fish population in the past ten years (Pitcher et al., 2013). There is no information regarding this attribute available yet. However, an increase in the number of people harvesting the lompa fish and the use of karoro and mosquito nets could lead to unsustainable conditions. High fishing intensity has been considered a cause of fisheries depletion or collapse of global fish stock (Hilborn et al., 2020; Hutchings \& Reynolds, 2004). Other distinguishing features apart from fishing intensity, habitat destruction, pollution, climate change, and other environmental factors also affect the stock abundance and fisheries depletion (Camara \& Santero-Sánchez, 2019; Hauge et al., 2009). The square correlation $\left(R^{2}\right)$ was 0.9507 , meaning $95.07 \%$ of the nine attributes used in the ecology domain have explained the sustainability of lompa fish. Therefore, other distinguishing features have less impact on the lompa fishery sustainability.

The Rapfish analysis was performed to other remaining sustainable dimensions (socio-economy, technical, and institutional), and the results are summarised in Table 5. From this table, it was clear that only the ecological dimension was considered to sustain; the other three dimensions were considered fair sustain according to the ecosystem approach to fisheries management (Pitcher et al., 2009). The sensitive attribute can either foster or inhibit the biological sustainability of the resources (Pitcher et al., 2013). Of 9 attributes in the ecological domain, the migratory range has high sensitivity $(\mathrm{RMS}=4.34)$. This attribute assesses any evidence of geographic reduction of the fish population in 10 past years Pitcher et al., 2013). The majority of the respondents responded that almost no sign of geographic reduction of lompa fish. Economically the lompa fish is not a target fish in fisheries. The only report that this fish is used as baitfish in skipjack fishery. Another source of income as the most sensitive attribute (RMS $=5.75)$ is more likely related to the income loss by local Haruku Village if the sasi event. The most sensitive attributes were gear selectivity $(\mathrm{RMS}=11.37)$ and gear side effect $(\mathrm{RMS}=11.08)$. A more detailed explanation is described in the discussion section.

The sasi institution in many villages has in decline or even 


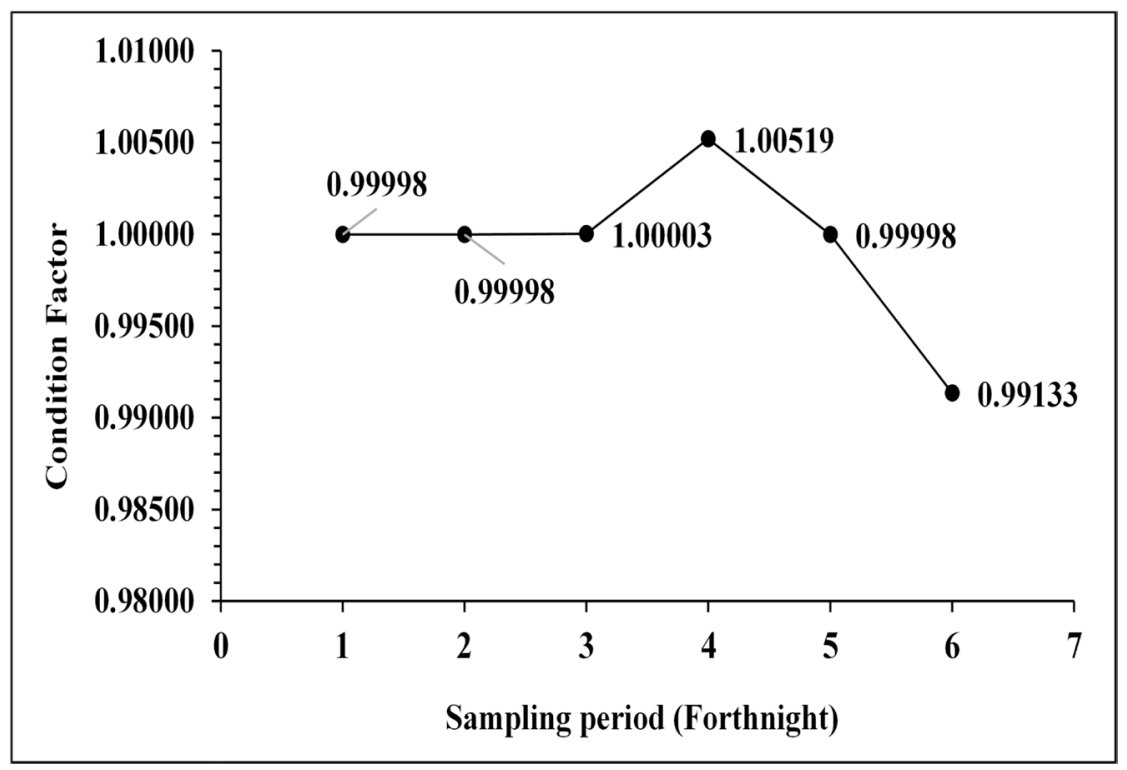

Fig. 4. The condition factor (Kn) of baelama anchovy (lompa) during study period.

Table 4. Sex ratio of baelama anchovy (lompa) from Haruku Village

\begin{tabular}{lllll}
\hline Sampling period & Male & Female & M/F & $x^{2}$ \\
\hline 1 & 38 & 53 & $0.7358: 1$ & 1.5119 \\
2 & 34 & 45 & $0.8333: 1$ & 1.2947 \\
3 & 37 & 51 & $0.7451: 1$ & 3.3575 \\
4 & 35 & 53 & $0.6731: 1$ & 1.1879 \\
5 & 32 & 55 & $0.6923: 1$ & 4.1940 \\
6 & 40 & 35 & $1.1429: 1$ & 0.2433 \\
Total & 223 & 285 & $0.7825: 1$ & 11.7894 \\
\hline
\end{tabular}

disappeared. Of 63 villages studied, 19 villages have permanent loss of the sasi, and others are weak in the implementation (Harkes \& Novaczek, 2002; Novaczek et al., 2001). In many coastal villages in Maluku, the community still depends on fish resources. Ineffective fish resources management has pushed the locals to fish outside their traditional fishing ground. A conflict sometimes arises between traditional fishers with commercial and even industrial ones. The need for effective conservation and management is more urgent than ever. Therefore, sasi, as an indigenous knowledge in the management of natural resources, needs to be preserved.

The conceptual model framework developed through the DPSIR approach was used to develop the sustainable management plan of lompa fishery from Haruku Village. The driver component (D) is the harvesting season (open sasi) of lompa fish. As a social and cultural event, the sasi has attracted many people not from the local community of Haruku but also neighbouring villages and even people from Ambon city. There is no information about the number of people who participate but visually, quite a sizable number of people. The pressure $(\mathrm{P})$ in this fishery comes from mosquito and karoro net used to harvest the lompa fish. At the same time, the state (S) component is the system of the lompa fishery (ecology, socio-economy, technical, institutional) affected by the pressure.

Fisheries sustainability is a multidimensional human endeavour with socio-economic, technological, and institutional implications. Therefore, the sustainable management of the fisheries should incorporate an analysis of the full social-economy, ecological, technical, and institutional before proposing a sustainable management strategy (Ernst et al., 2013; Weber et al., 2019). The causal-loop diagram approach based on DPSIR was used to develop a sustainable management strategy for the lom$p a$ fishery. Fig. 6 shows the conceptual model framework based on the DPSIR approach incorporating ecological, socio-economy, technical, and institutional dimensions established for the sustainable management strategy of the lompa fishery.

In the last 10-15 years, the number of people participating in the lompa fish harvesting season, locally called buka sasi, has increased significantly (personal communication). This event has become a socio-cultural festival that attracts many people (Soselisa, 2019). As the number of people participating in the 

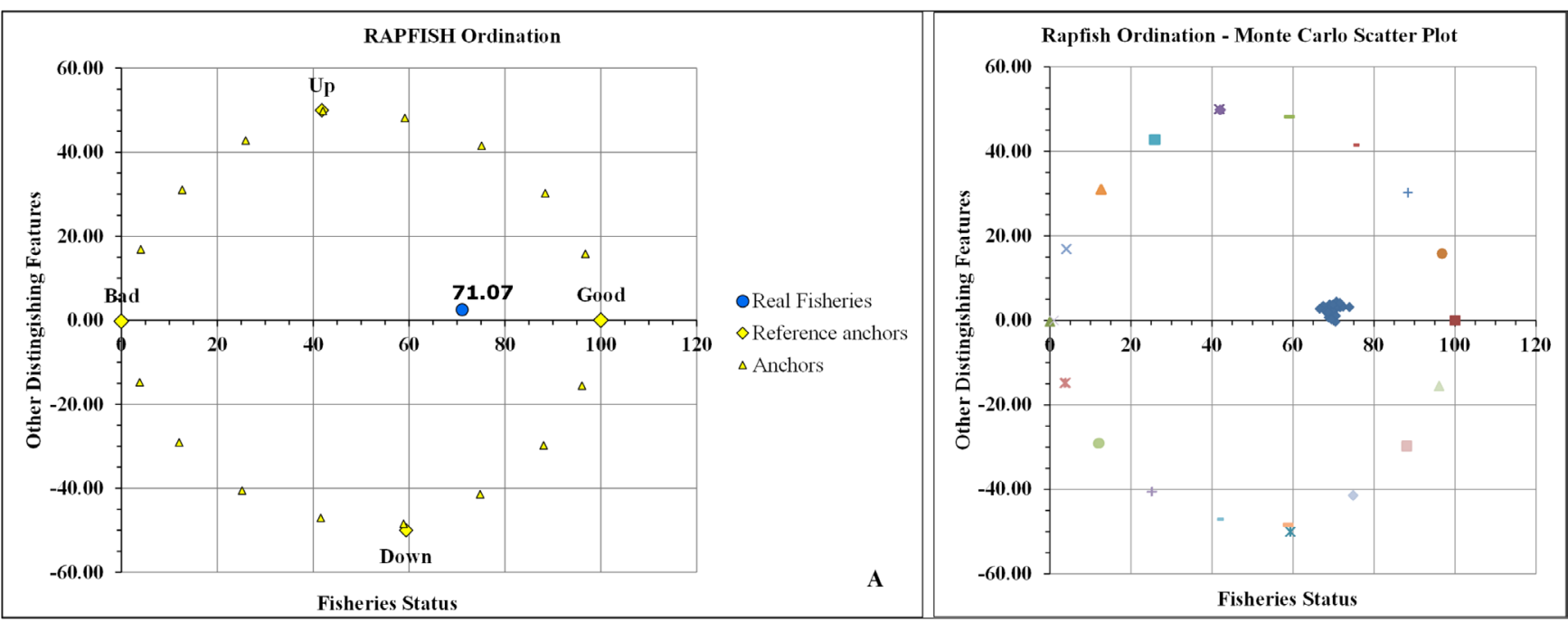

Fig. 5. Rapfish ordination (A) and Monte Carlo Scatter Plot (B) analysis of ecological sustainability status of baelama anchovy (lompa) fishery at Haruku Village.

Table 5. Percent of female lompa fish with their maturity stage and approximate size group

\begin{tabular}{|c|c|c|c|c|c|c|c|c|c|c|c|c|}
\hline \multirow[t]{3}{*}{ Size group (mm) } & \multirow{2}{*}{\multicolumn{2}{|c|}{ Individu number }} & \multicolumn{10}{|c|}{ Maturity stage } \\
\hline & & & \multicolumn{5}{|c|}{ Female } & \multicolumn{5}{|c|}{ Male } \\
\hline & $\mathrm{F}$ & M & 1 & II & III & IV & V & 1 & II & III & IV & V \\
\hline $9.0-9.4$ & 0 & 0 & - & - & - & - & - & - & - & - & - & - \\
\hline $9.5-9.9$ & 2 & 2 & - & 2 & - & - & - & 1 & 1 & - & - & - \\
\hline $10.0-10.4$ & 2 & 1 & - & 1 & 1 & - & - & - & 1 & - & - & - \\
\hline $10.5-10.9$ & 3 & 2 & 1 & - & 1 & 1 & - & - & 1 & 1 & - & - \\
\hline $11.0-11.4$ & 20 & 7 & 8 & 3 & 8 & 1 & - & - & 2 & 4 & 1 & - \\
\hline $11.5-11.9$ & 39 & 13 & - & - & 5 & 12 & 22 & & 1 & 1 & 3 & 8 \\
\hline $12.0-12.4$ & 10 & 7 & 2 & - & - & - & 8 & 1 & 1 & - & 2 & 3 \\
\hline $12.5-12.9$ & 4 & 4 & 1 & - & - & - & 3 & 1 & 1 & & 1 & 1 \\
\hline $13.0-13.4$ & 1 & 1 & & - & - & - & 1 & - & - & - & 1 & - \\
\hline Total & 81 & 37 & 12 & 6 & 15 & 14 & 34 & 3 & 8 & 6 & 8 & 12 \\
\hline Percentage & & & 10.17 & 5.08 & 12.71 & 11.86 & 28.81 & 2.54 & 6.78 & 5.08 & 6.78 & 10.17 \\
\hline
\end{tabular}

harvesting season (open sasi) increases, the number of fishing units will also increase. The use of karoro and mosquito net, which is unselective fishing gear, will undoubtedly threaten lompa fish sustainability. Fishing can cause many disruptions in the ecosystem, such as fish population decline, change in the physical structure of the environment, reduction of a top predator, size sex, etc. (Breen et al., 2016; Camara \& Santero-Sánchez, 2019; Porobic et al., 2019).

Non-selective fishing gears such as trawl nets and purse seines catch $74 \%$ of total juvenile and young fish without giving a chance to spawn at least once (Dineshbabu et al., 2012; Remesan et al., 2009). Nets made of very small netting will capture all sizes of fishes, a significant share of which are liable to be discarded. Such practices will affect the biodiversity of all the associated water bodies. The karoro net and mosquito net will certainly catch small lompa fish and produce bycatch/discard fish (Table 6).

Interviewed with local people of Haruku Village revealed that as long as they experience, almost no data collecting concerning the number of lompa fish harvested during the open 


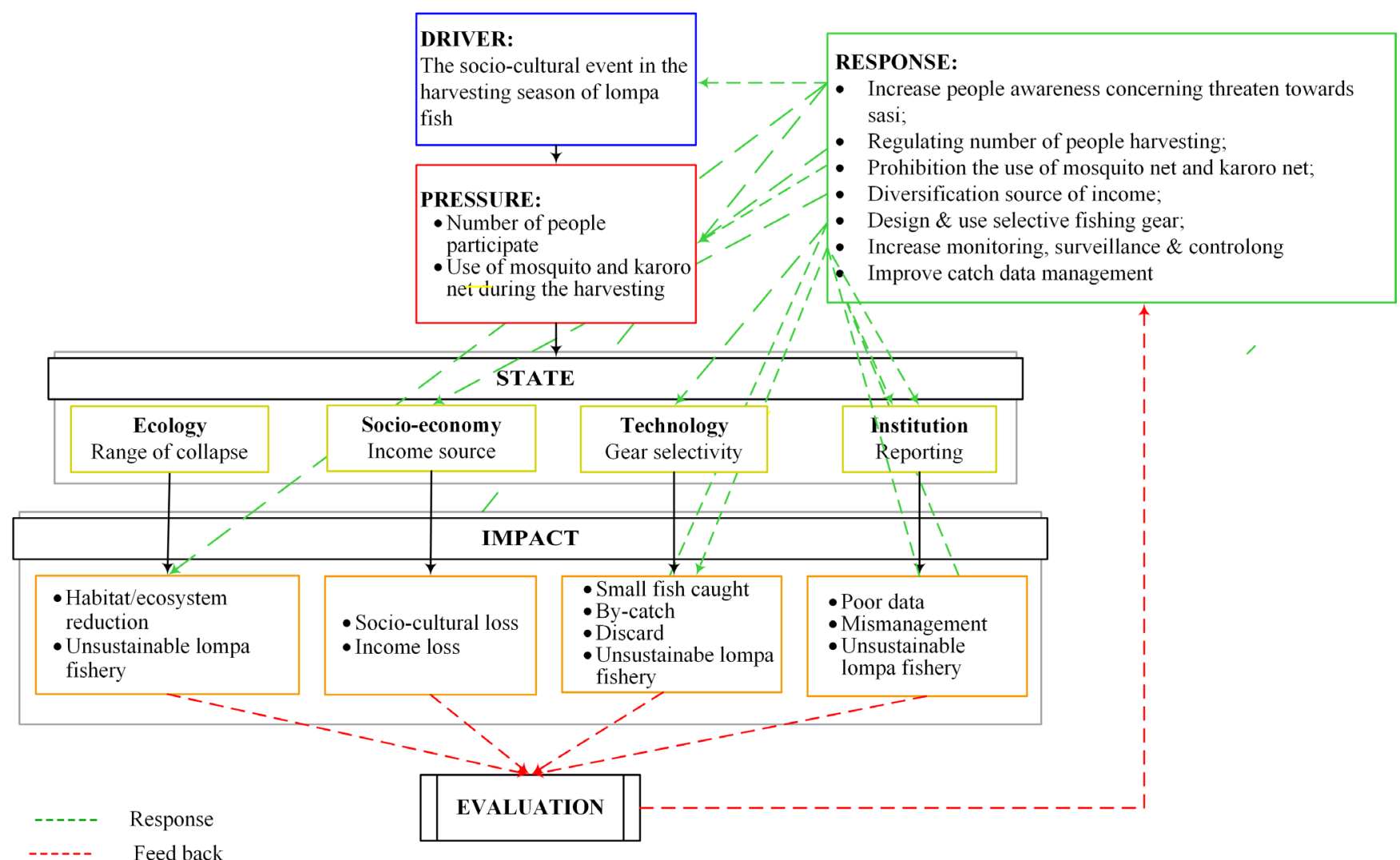

Fig. 6. The DPSIR conceptual model framework showing sustaianble management strategy for lompa fishery. DPSIR, driverpressure-state-impact-response.

Table 6. Multidimensional sustainablility status of lompa fishery

\begin{tabular}{lllllll}
\hline Dimension & Sustainble status (\%) & Stress & Square correlation & Sensitive attribute & RMS & Remark \\
\hline Ecology & 71.07 & 0.1418 & 0.9507 & Range of collapse & 4.34 & Sustain \\
Socio-economy & 69.64 & 0.1327 & 0.9527 & Source of income & 5.75 & Fair sustain \\
Technology & 52.58 & 0.1364 & 0.9403 & Gear selectivity & 11.37 & Fair sustain \\
Institutional & 53.11 & 0.1465 & 0.9463 & Reporting & 4.39 & Fair sustain \\
\hline Mean & 61.60 & 0.1394 & 0.9475 & & & Fair sustain \\
\hline
\end{tabular}

sasi. Field observation during the open sasi event in 2018 also confirmed no data collecting on the number of fish caught. This indicates a poor data condition on the management of lompa fish through the sasi mechanism. Failure to assess the status and productivity of fish stocks can increase the risk of stock collapse and lead to loss of social and economic benefits associated with sustainable yield. Limitations in data quantity and quality can lead to model misspecification and erroneous data treatments, potentially causing important changes in model outputs and subsequent mismanagement implications (Apel et al., 2013; Bradley et al., 2019).

\section{Discussion}

From Fishbase information (Froese \& Pauly, 2021), it was found that the maximum total length of baelama anchovy ( $T$. baelama) was $16.0 \mathrm{~cm}$. However, from this study, the maximum length was $14.3 \mathrm{~cm}$ which is less than the maximum total length 
recorded from Fishbase. A workshop by NOAA on tuna baitfish shows that this fish is used as a baitfish and has a size between 7.5-15.5 cm total length (Shomura, 1977), while Marichamy (1970) on T. baelama from Andaman sea found the total length between $5.7-13.2 \mathrm{~cm}$. These findings show a variation in length size, with the maximum total length size recorded being 14.3 $\mathrm{cm}$. The differences could be due to the study site, which relates to environmental conditions, food availability, season (Jisr et al., 2018; Mazumder et al., 2016).

The pool correlation coefficient from the length-weight relationship of the lompa fish found from this study was 0.89577 with the coefficient of determination $R^{2}=0.8022(p<0.05)$. The correlation coefficient of females and males was 0.9475 and 0.9462 , and the coefficient of determination $R^{2}$ was 0.8978 and 0.8953 , respectively. Other studies on the length-weight relationship found the correlation coefficient value between 0.9080 to 0.9751 of some fish species in tropical rainforest river in South-east Nigeria (Adaka et al., 2015); 0.9731 in Leiognathus equulus from Teluk Pabean of Western Java (Aditriawan \& Runtuboy, 2017); 0.9925 to 0.9930 in Selena dorsalis from the continental shelf of Coast of Ivory of West Africa (Arra et al., 2018); between 0.2258 to 0.9476 in 9 fish species inhabiting the marine area of Eastern Mediterranean, Tripoly-Lebanon (Jisr et al., 2018). All these findings explain differences in the lengthweight relationship, which might be due to species differences, geographical area, the number of samples used in the analysis (Adaka et al., 2015; Jisr et al., 2018).

From the length-weight relationship of lompa fish on a monthly basis, it was found that the $b$ value varies between months, with the value range between 1.6093-1.9024. From 3,929 length-weight relationships analyzed, the $b$ value range from 2.5 to 3.5 , and only a few species outside this range (Froese, 2006). A study on the anchovy Ciolia dussumieri Valenciennes of the north coast of India found the $b$ value for males was 2.74 and for females was 1.47 (Mahapatra et al., 2015). In the study on the length-weight relationship of fish inhabiting the marine area of the Eastern Mediterranean city of Tripoly, the $b$ value found varies between 0.823 to 3.016 for 11 fish species (Jisr et al., 2018). The alteration in $b$ value primarily arises from a change in fish weight affected by environmental factors like temperature, food supply, spawning conditions, and other factors like sex, age, fishing time and area, and fishing vessels (Bagenal \& Tesch, 1978; Nair et al., 2021).

The study by Marichamy (1970) found that the sex ratio of T. baelama was dominated by a female. In the same study, the analysis by different size groups shows that the males dominating the female in size less than $90 \mathrm{~mm}$, but on larger sizes of more than $100 \mathrm{~mm}$, were dominated by a female. The overall sex ratio of T. dussumieri from the Ratnagiri coast, India, was 1:1.14, with females dominating the males (Pawase et al., 2020). Another study on T. mystax found the sex ratio of 1.26:1 with females dominating the male (Hoda, 1976), 1:0.93 of the same species (Kende et al., 2020; Pawase et al., 2020). A study on the sex ratio on African moonfish, Selene dorsalis, from West Africa shows the sex ratio of males to females was 1:0.97 (Arra et al., 2018). All these studies show a variation in sex ratio based on size, location, and sampling period. In fishes, sex is determined by genetics, the environment, or an interaction of both. Temperature is among the most important environmental factors affecting sex determination (Geffroy \& Wedekind, 2020).

A fluctuation in relative condition factor was also found in T. baelama from the Andaman sea. The relative condition index fluctuated over time from 1968 to1970, with the value ranger from 0.800 to 1.100 (Marichamy, 1970). A study on other baelama fish (T. dussumieri) also shows a fluctuation of relative condition factor over time, with the value ranging from 0.900 to 1.07 (Pawase et al., 2020). The relative condition factor of ponyfish L. equulus from Pabean Bay of West Java, Indonesia, from April 2016 to March 2017 vary between 0.81 to 1.34 (Aditriawan \& Runtuboy, 2017). Another study on the condition factor of African moonfish $S$. dorsalis found that combined sexes range from 1.45 to 2.39 . For males range from $1.45-2.25$, and for females from 1.51-2.39 (Arra et al., 2018). The condition factor (index) for nine species from the Eastern Mediterranean City of Tripoli-Lebanon ranges from 0.960 to 1.029 (Jisr et al., 2018). The condition factor state the well-being for the fish where fish with condition factor $<1$ is considered not in good condition, while the condition factor is $>1$, meaning the fish is in good condition (Adaka et al., 2015; Arra et al., 2018; Jisr et al., 2018). This study and some other studies mentioned show a fluctuation in the condition factor of the fish. Many factors affect the condition factor of fish, including reproductive cycles, availability of food, as well as habitat, and environmental factors (De Giosa et al., 2014; Jisr et al., 2018).

Among population parameters of fish like length-weight relationship, sex ratio, gonadosomatic index, and length at first maturity, the maturity of the fish is one of the vital parameters in fishery management. The information derived from the aspect of fish maturity is valuable for estimating spawning potential and recruitment prediction of a fish stock, which is essential 
in managing the fish (Arra et al., 2018; Nair et al., 2021). Unfortunately, the information of population parameters of lompa fish is very scarce. This study is most probably the first study on the population parameters of the lompa fish. For the maturity index, Marichamy (1970) has the information on the maturity stage of T. baelama and revealed that the baelama anchovy with the size above $125 \mathrm{~mm}$ was found in either mature or spent. It was also presumed that the length at the first maturity of this species was $107 \mathrm{~mm}$. A study on the female Hamilton's anchovy (T. hamiltonii, Gray, 1835) found that length at first maturity was $171.05 \mathrm{~mm}$ (Kamal et al., 2020). Another study on T. mystax of the Tuticorin coast, east coast of India, found that the first maturity was $122 \mathrm{~mm}$ for females (Nallu Chinnappan \& Jeyabaskaran, 1991).

All the information on the maturity of the anchovy fish, in general, explains that the maturity, in particular length at first maturity, was varied between species, area, sex, and time. This study displays that many lompa individuals were found in the mature stage and spent. The harvesting season (open sasi) of lompa fish is usually scheduled in October but was postponed since the environmental condition was unsuitable (Kissya, personal communication). If the harvesting season could have been done, it could not be a proper time since much lompa fish is in their spawning season. More research should be conducted covering another period of time to get a more explicit description of the maturity index of the fish and spawning peak seasons, also the size at first maturity.

The sustainability status of fish stock is vital in fisheries management. On the global scale, the state of marine fishery resources, based on FAO's long-term monitoring of assessed marine fish stocks, has continued to decline. The proportion of fish stocks within biologically sustainable levels decreased from $90 \%$ in 1974 to $65.8 \%$ in 2017 (FAO, 2020). Information on the sustainability of lompa fish is very limited; the only study on this fish status was reported by Soselisa (2019) that the fish is under threat, while Talakua (2011) had reported a change in habitat productivity of the lompa fish ecosystem. The study conducted by Soselisa (2019) is mainly based on observing fishing gear used during open sasi and some interviews with people participating in the open sasi event. The conclusion was based on the assumption of the side effect of unselective fishing gear (karoro net and mosquito net) used in harvesting lompa fish. In comparison, this study covers four dimensions in sustainability analysis comprise 36 attributes. The most sensitive attribute for each domain is different (Table 5). However, the highest one is gear selectivity, indicating the effect of using a mosquito net and karoro net in harvesting the lompa fish has high negative sensitivity towards sustainability of lompa fish.

The present study shows that the overall sustainability of lompa fish was $61.60 \%$ from $100 \%$ sustainable scale and was considered fair sustain according to the ecosystem-based to fisheries management for small-scale fishery (Pitcher et al., 2009). Factors contributing to this sustainability were a fishing gear side effect and reporting, especially the number of fish caught during harvesting season. A study on the catch rate of two-banded seabream Diplodus vulgaris in the Mediterranean shows a negative impact on catch rate due to environmental change and fishing pressure (Baptista et al., 2016). Other factors that could affect the sustainability status of fisheries are the use of non-selective fishing gear, fishing pressure, IUU fishing, good governance and, the conflict between fisher for the same species and fishing ground (Dunbar et al., 2021; FAO, 2020). In the case of the lompa fishery, the fishing pressure shown by the increase in the number of people participating and fishing gear selectivity is the main factor threatening lompa fish sustainability.

The main driver (D) in the lompa fishery is the harvesting season, or locally called "buka sasi." This event is conducted once a year and recently attracted many people from Haruku Village and neighbouring villages and Ambon. There is no exact information on the number of people who participate directly in harvesting the fish, but quite sizeable. Another issue in the harvesting season is unfriendly fishing gear, namely mosquito net and karoro net (mini beach seine with small mesh size) used during harvesting season. These two main issues, the number of people participating in the harvesting season and fishing gear used, then used to construct the conceptual model with DPSIR to propose the management strategy for sustainable lompa fish (Fig. 6).

Based on the causal loop diagram displayed on DPSIR conceptual model framework (Fig. 6), the management strategies taken are to increase the awareness of the community regarding a threat faced by lompa fish during the lompa fish harvesting event, regulating the number of people participate in the harvesting event, prohibiting the use of mosquito net and karoro net, diversification of source of income of the local community, design and use of friendly fishing gear, increase monitoring, surveillance, controlling, and improve catch management data. Regulating the number of people and the gear used is essential for sustainable management fishery (Angel et al., 2019; Nilsson et al., 2018). The introduction of new selective fishing gear, 
monitoring, controlling, and surveillance which provide essential data (Bahri et al., 2021; McDonald et al., 2017), will be used to evaluate the lompa fishery condition and develop an adaptive management strategy.

Since the Haruku community does not entirely depend on the lompa fish due to their other income sources, this condition should be maintained or even diversified. The income of the Haruku community and the social and culture of the community should be monitored and evaluated regularly. A response should be taken in the response when there is a sign of alteration in these components. It is recognized that fisheries sustainability is a multidimensional human endeavor with socio-economic, technological, ethical, or institutional implications. Social responsibility by the community (stakeholder) participation also increases the sustainability of the resources (Camara \& Santero-Sánchez, 2019; Halls et al., 2017).

For the technology and institutional domains, the sustainable management strategy derived for lompa fish sustainable management cover prohibits the use of mosquito net and karoro net, introduces selective fishing gear, and establishes regular monitoring, surveillance, and control (MSC). The information obtained from the MSC will then be used to evaluate the lompa fishery status and then establish a management strategy if required. Monitoring, controlling, and surveillance is an aspect of oceans and fisheries management often overlooked, but in reality, it is key to the successful implementation of any planning strategy. These components are an integral and vital component for implementing fisheries management plans (Cremers et al., 2020; Flewwelling, 2001).

\section{Conclusion}

This study shows that most lompa fish length intervals are between $10.0-11.4 \mathrm{~cm}$. A high positive relationship was found between total length and weight with a growth pattern of negative allometric. There is a difference between the sex ratio of males to females, with females dominating the lompa fish composition. There was a variation in body condition index over time and variation that could be due to reproductive status. There was also a variation in maturity index, with mature and spent stage having the highest percentage. The average sustainability status of lompa fish managed through the sasi approach was fair sustained. The ecological domain had the highest sustainable status, while the technological domain had the lowest. According to the DPSIR conceptual model framework, seven strate- gies were proposed for sustainable management for the lompa fishery. More research should be conducted to cover spawning season and length and body size composition to predict length at first maturity.

\section{Competing interests}

No potential conflict of interest relevant to this article was reported.

\section{Funding sources}

Not applicable.

\section{Acknowledgements}

The authors would like to thank the Kewang of Haruku Village, particularly the Kewang Chief, Mr. Eliza Kyssia, for providing the opportunity to do this study and the people of Haruku Village for their hospitality during the research.

\section{Availability of data and materials}

Upon reasonable request, the datasets of this study can be available from the corresponding author.

\section{Ethics approval and consent to participate}

This article does not require IRB/IACUC approval because there are no human and animal participants.

\section{ORCID}

Johannes M.S. Tetelepta https://orcid.org/0000-0002-4888-0874 Yuliana Natan https://orcid.org/0000-0002-8439-2720 Jesaja A. Pattikawa https://orcid.org/0000-0003-1501-0036 Agil S. Bernardus https://orcid.org/0000-0002-2882-7443

\section{References}

Adaka G, Ndukwe E, Nlewadim A. Length-weight relationship of some fish species in a tropical rainforest river in SouthEast Nigeria. Transylv Rev Syst Ecol Res. 2015;17:73-8.

Adhuri DS. How can traditional marine resource management support a responsible fishery? Lesson learned from Maluku. In: Proceedings of the Twelfth Biennial Conference of the International Institute of Fisheries Economics \& Trade (IIFET); 2004; Tokyo, Japan.

Aditriawan RM, Runtuboy N. Length-weight relationship and condition factor of common ponyfish, Leiognathus equulus (Forsskål, 1775) in Pabean Bay, Indramayu, West Java. J 
Iktiologi Indones. 2017;17:311-6.

Angel E, Edwards DN, Hawkshaw S, Wor C, Parlee CE. An indicator framework to support comprehensive approaches to sustainable fisheries management. Ecol Soc. 2019;24:12.

Apel AM, Fujita R, Karr K. Science-based management of data-limited fisheries: a supplement to the catch share design manual [Internet]. Environmental Defense Fund. 2013 [cited 2021 Oct 31]. https://fisherysolutionscenter.edf.org/ sites/catchshares.edf.org/files/CSDM_Sup_Data_Limited_ Fisheries.pdf

Arra S, Sylla S, Kouame AC, Zan-BI TT, Ouattaraw M. Reproductive biology of the African moonfish, Selene dorsalis (Gill, 1862) (Carangidae) in continental shelf of Côte d'Ivoire fishery (West Africa). Int J Fish Aquat Stud. 2018;6:358-63.

Bahri T, Vasconcellos M, Welch DJ, Johnson J, Perry RI, Ma X, et al. Adaptive management of fisheries in response to climate change. Rome, FAO; 2021. FAO Fisheries and Aquaculture Technical Paper No. 667.

Bagenal TB, Tesch FW. Age and growth. In: Bagenal TB, editor. Methods for assessment of fish production in fresh waters. 3rd ed. Oxford: IBP Handbook No. 3, Blackwell Science; 1978.

Balzan MV, Pinheiro AM, Mascarenhas A, Morán-Ordóñez A, Ruiz-Frau A, Carvalho-Santos C, et al. Improving ecosystem assessments in Mediterranean social-ecological systems: a DPSIR analysis. Ecosyst People. 2019;15:136-55.

Baptista V, Campos CJA, Leitão F. The influence of environmental factors and fishing pressure on catch rates of Diplodus vulgaris. Estuaries Coasts. 2016;39:258-72.

Batiran K, Salim I. A tale of two kewangs: a comparative study of traditional institutions and their effect on conservation in Maluku. For Soc. 2020;4:81-97.

Benedict OO, Yemi AS, Isaac TO. Length-weight relationship, condition factor and sex ratio of forty six important fishes in a tropical flood river. Res J Fish Hydrobiol. 2009;4:65-72.

Bradley D, Merrifield M, Miller KM, Lomonico S, Wilson JR, Gleason MG. Opportunities to improve fisheries management through innovative technology and advanced data systems. Fish Fish. 2019;20:564-83.

Breen M, Graham N, Pol M, He P, Reid D, Suuronene P. Selective fishing and balanced harvest. Fish Res. 2016;184:2-8.

Camara A, Santero-Sánchez R. Economic, social, and environmental impact of a sustainable fisheries model in Spain. Sustainability. 2019;11:6311.

Clarke KR, Gorley RN, Somerfield PJ, Warwick RM. Change in marine communities: an approach to statistical analysis and interpretation. 3rd ed. Plymouth, UK: PRIMER-E; 2014.

Cremers K, Wright G, Rochette J. Strengthening monitoring, control and surveillance of human activities in marine areas beyond national jurisdiction: challenges and opportunities for an international legally binding instrument. Mar Policy. 2020;122:103976.

De Giosa M, Czerniejewski P, Rybczy A. Seasonal changes in condition factor and weight-length relationship of invasive Carassius gibelio (Bloch, 1782) from Leszczynskie Lakeland, Poland. Adv Zool. 2014;2014:678763.

Díaz ME, Figueroa R, Alonso MLS, Vidal-Abarca MR. Exploring the complex relations between water resources and social indicators: the Biobío basin (Chile). Ecosyst Serv. 2018;31:84-92.

Dineshbabu AP, Muthiah C, Sasikumar G, Rohit P, Bhat US. Impact of non-selective gears on kingseer, Scomberomorus commerson fishery in Karnataka. Indian J Geo-Mar Sci. 2012;41:3:265-71.

Dunbar A, Mungai D, Muthee JK. Factors influencing the sustainable utilization of artisanal fisheries: a case of west point, Liberia. Int J Fish Aquat Stud. 2021;9:52-9.

Effendie MI. Biologi perikanan. Yogyakarta, Indonesia: Yayasan Pusaka Nusantama; 1997.

Elliott M, Burdon D, Atkins JP, Borja A, Cormier R, de Jonge $\mathrm{VN}$, et al. "And DPSIR begat DAPSI(W)R(M)!”: a unifying framework for marine environmental management. Mar Pollut Bull. 2017;118:27-40.

Ernst B, Chamorro J, Manríquez P, Orensanz JML, Parma AM, Porobic J, et al. Sustainability of the Juan Fernández lobster fishery (Chile) and the perils of generic science-based prescriptions. Glob Environ Change. 2013;23:1381-92.

Food and Agriculture Organization of the United Nations [FAO]. The State of World Fisheries and Aquaculture 2020: Sustainability in action. Rome: FAO; 2020.

Flewwelling P. Fisheries management and MCS in South Asia: comparative analysis. Rome: FAO; 2001.

Froese R, Pauly D. Thryssa baelama (Forskal, 1775) [Internet]. Fishbase. 2021 [cited 2021 Jun 19]. https://www.fishbase.se/ summary/582

Froese R. Cube law, condition factor and weight-length relationships: history, meta-analysis and recommendations. J Appl Ichthyol. 2006;22:241-53.

Gari SR, Newton A, Icely JD. A review of the application and evolution of the DPSIR framework with an emphasis on 
coastal social-ecological systems. Ocean Coastal Manag. 2015;103:63-77.

Geffroy B, Wedekind C. Effects of global warming on sex ratios in fishes. J Fish Biol. 2020;97:596-606.

Halls AS, Mustafa MG, Dickson M. Community-based fisheries management approach adopted in Bangladesh. Adv Res. 2017;11:1-17.

Harkes I. An institutional analysis of sasi laut, a fisheries management system in Indonesia [Internet]. 1999 [cited 2021 October 31]. http://pubs.iclarm.net/Pubs/Way\%20Forward/19\%20 Harkes.pdf

Harkes I, Novaczek I. Presence, performance, and institutional resilience of sasi, a traditional management institution in Central Maluku, Indonesia. Ocean Coast Manag. 2002;45:237-60.

Hauge KH, Cleeland B, Wilson DC. Fisheries depletion and collapse [Internet]. International Risk Government Council Report. 2009 [cited 2021 Oct 2021]. https://irgc.org/ wp-content/uploads/2018/09/Fisheries_Depletion_full_ case_study_web.pdf

Hasan NH. Preserving and development the myth of lompa fish: Live-Straus structuralism review. Ambon, Indonesia: Kantor Bahasa Maluku Badan Pengembangan dan Pembinaan Bahasa Kementerian Pendidikan dan Kebudayaan; 2017.

Hilborn R, Amoroso RO, Anderson CM, Baum JK, Branch TA, Costello C, et al. Effective fisheries management instrumental in improving fish stock status [Internet]. PNAS Latest Article. 2020;117:2218-24.

Hoda SMS. Reproductive biology and length-weight relationship of Thryssa dussumieri (Valenciennes) of the Pakistan coast. J Mar Biol Assoc India. 1976;18:272-87.

Holden MJ, Raitt DFS. Manual of fishery science, part 2 methods of resource investigation and their application. Rome: FAO; 1974. FAO Fisheries Technical Paper No 115, Rev. 1.

Hutchings JA, Reynolds JD. Marine fish population collapses: consequences for recovery and extinction risk. BioScience. 2004;54:297-309.

Jisr N, Younes G, Sukhn C, El-Dakdouki MH. Length-weight relationships and relative condition factor of fish inhabiting the marine area of the Eastern Mediterranean city, Tripoli-Lebanon. Egypt J Aquat Res. 2018;44:299-305.

Karepisina SS, Susilo E, Indrayani E. Customary law existence in the protection of lompa fish sasi at Haruku Village, Cenral Maluku District. ECSOFiM. 2017;1;1:25-41.
Kamal MM, Ernawati Y, Dewi NN. Length at first maturity, spawning time, and reproductive output in the females of Hamilton's anchovy (Thryssa hamiltonii Gray, 1835). J Biol Tropis. 2020;20:1-6.

Kavanagh P, Pitcher TJ. Implementing microsoft excel software for Rapfish: a technique for the rapid appraisal of fisheries status. Vancouver, BC: Fisheries Center; 2004.

Kell LT, Luckhurst BE. Extending the indicator-based ecosystem report card to the whole ecosystem; a preliminary example based on the Sargasso Sea. Collect Vol Sci Pap ICCAT. 2018;75:258-75.

Kende DR, Nirmale VH, Gurjar UR, Qayoom U, Syed N, Pawar RA. Biometric analysis of moustached Thryssa mystax (Bloch and Schneider, 1801) along the Ratnagiri coast of Maharashtra, India. Indian J Fish. 2020;67:2:110-3.

King M. Fisheries biology, assessment and management. 2nd ed. Hoboken, NJ: John Wiley \& Sons; 2007.

Kissya E. Sasi aman Haru-ukui: Traditional management of sustainable natural resources in Haruku. Jakarta: Sejati Foundation; 1995.

Lellotery H, Hitipeuw JC, Sahusilawane J. The role of traditional conservation towards bird species biodiversity in 543 some villages of South Leitimur sub-district. Jurnal Agroforestri. 2007;2:34-40.

Mahapatra BK, Pradhan A, Lakra WS. Morphometrics, lengthweight relationship and condition factor of Coilia dussumieri Valenciennes, 1848 from North-East coast of India. Int J Fish Aquat Stud. 2015;3:35-9.

Marichamy R. Maturity and spawning of the anchovy, Thrissina baelama (Forskal) from the Andaman sea. Indian J Fish. 1970;17:179-87.

Marjanto DK. The cultural valus exist in the tradition of lompa fish sasi in Haruku Village, Central Maluku District. Patrawidya. 2015;16:311-326.

Martin DM, Piscopo AN, Chintala MM, Gleason TR, Berry W. Developing qualitative ecosystem service relationships with the Driver-Pressure-State-Impact-Response framework: a case study on Cape Cod, Massachusetts. Ecol Indic. 2018;84:404-15.

McDonald G, Harford B, Arrivillaga A, Babcock EA, Carcamo $\mathrm{R}$, Foley J, et al. An indicator-based adaptive management framework and its development for data-limited fisheries in Belize. Mar Policy. 2017:76:28-37.

Mazumder SK, Das SK, Bakar Y, Ghaffar MA. Effects of temperature and diet on length-weight relationship and condi- 
tion factor of the juvenile Malabar blood snapper (Lutjanus malabaricus Bloch \& Schneider, 1801). J Zhejiang Univ Sci B. 2016;17:580-90.

Nair PG, Joseph S, Kripa V, Pillai VN. Population growth and maturity characteristics of Commerson's anchovy (Stolephorus commersonnii Lacepède, 1803) along the southwest coast of India. Indian J Geo Mar Sci. 2021;50:141-7.

Nallu Chinnappan I, Jeyabaskaran Y. Observations on the biology of Thryssa mystax off Tuticorin coast, Gulf of Mannar, east coast of India. J Mar Biol Assoc India. 1991;33:49-54.

Natan Y, Tetelepta JMS, Pattikawa JA, Ongkers OTS. Incorporating the ecological, socio-economic and institutional conceptual model framework for sustainable management of small-scale mud crab (Scylla serrata) fishery in Western Seram Regency, Indonesia. Environ Nat Resour J. 2021;19:207-19.

Nikijuluw VPH. Community-based fishery management (sasi) in Central Maluku. Indones Agric Res Dev J. 1995;17:33-9.

Nilsson M, Chisholm E, Griggs D, Howden-Chapman P, McCollum D, Messerli P, et al. Sustain Sci. 2018;13:1489-1503.

Novaczek I, Harkes IHT, Sopacua J, Tatuhey MDD. An institutional analysis of Sasi laut in Maluku, Indonesia. Penang, Malaysia: ICLARM; 2001. ICLARM Technical Report 59.

Pauly D. Fish population dynamics in tropical waters: a manual for use with programmable calculators. Penang, Malaysia: ICLARM; 1984. ICLARM Contribution No. 143.

Pawase SV, Nirmale VH, Bhosale BP, Pawar RA, Sawant MS, Kende DR. Study on biology of Thryssa dussumieri (Valenciennes, 1848) from the coast of Ratnagiri, Maharashtra, India. Indian J Geo Mar Sci. 2020;49:87-94.

Persada NPR, Mangunjaya FM, Tobing ISL. Sasi as cultural natural resources conservation in Maluku Province. Jurnal Ilmu dan Budaya. 2018;41;59:6869-900.

Pitcher TJ. RAPFISH, a rapid appraisal technique for fisheries, and its application to the code of conduct for responsible fisheries. Rome: FAO; 1999. FAO Fisheries Circular No. 947.

Pitcher TJ, Kalikoski D, Short K, Varkey D, Pramoda G. An evaluation of progress in implementing ecosystem-based management of fisheries in 33 countries. Mar Policy. 2009;33:223-32.

Pitcher TJ, Lam ME, Ainsworth C, Martindale A, Nakamura K, Perry RI, et al. Improvements to Rapfish: a rapid evaluation technique for fisheries integrating ecological and human dimensions. J Fish Biol. 2013;83:865-89.

Pitcher TJ, Preikshot D. RAPFISH: a rapid appraisal technique to evaluate the sustainability status of fisheries. Fish Res. 2001;49:255-70.

Porobic J, Fulton EA, Parada C, Frusher S, Ernst B, Manríquez $\mathrm{P}$. The impact of fishing on a highly vulnerable ecosystem, the case of Juan Fernández Ridge ecosystem. PLOS ONE. 2019;14:e0212485.

Remesan MP, Pravin P, Meenakumari B. Non-selective fishing gears and sustainability issues in the Hooghly-Maltah estuary in West Bengal, India. Asian Fish Sci. 2009;22:297-308.

Shomura RS. Collection of tuna baitfish papers. Washington, DC: Department of Commerce; 1977. NOAA Technical Report NMFS Circular 408.

Soselisa HL. Sasi lompa: a critical review of the contribution of local practices to sustainable marine resource management in Central Maluku, Indonesia. IOP Conf Ser Earth Environ Sci. 2019;339:012013.

Steel RGD, Torrie JH. Principle and procedure of statistics. A biometrical approach. 2nd ed. New York, NY: McGraw-Hill; 1980.

Talakua W. Change in productivity of sasi lompa area in Haruku Village, Pulau Haruku Sub-district, Central 605 Maluku Regency. Jurnal Triton. 2011;7;2:71-8.

Weber CT, Borit M, Aschan M. An interdisciplinary insight into the human dimension in fisheries models. A systematic literature review in a European Union context. Front Mar Sci. 2019;6:369.

Zador ZG, Gaichas SK, Kasperski S, Ward CL, Blake RE, Ban $\mathrm{NC}$, et al. Linking ecosystem processes to communities of practice through commercially fished species in the Gulf of Alaska. ICES J Mar Sci. 2017;74:2024-33.

Zar JH. Biostatistical analysis. 5th ed. New Jersey, NJ: Prentice Hall International; 2014. 